\title{
The Existence of Jipang Village as a Collective Builder Cepu Community in Blora Regency
}

\author{
Sukarjo Waluyo*, Redyanto Noor Ary Setyadi \\ Faculty of Humanities, Diponegoro University, Semarang, Indonesia
}

\begin{abstract}
The problem of locality and local wisdom in Indonesia has become a problem that has got much attention in the post-Reformation 1998. Cepu District in Blora Regency is now starting to rise to revitalize the glory of the Jipang Duchy in the past. Meanwhile, Duke of Arya Penangsang who ruled Jipang in the mid-16th century was a symbol of their hero. The chronicle of Babad Tanah Djawi and the Javanese Mataraman/inland culture have built a hegemonic representation whose traces are manifested in the art of Solo kethoprak (Mataraman). Meanwhile, Kethoprak Pati (coastal area) which accommodates spoken stories in Coastal Java builds a representation that has a resistance pattern. Cepu is a city that inherits the existence of the figure of Arya Penangsang and Kadipaten Jipang. The revitalization of the glory of the Jipang Duchy in Cepu is a resistance patterned representation. The existence of Jipang Village [1] as a collective memory builder of the Cepu community in Blora Regency is very important. Jipang Village, in the past was the capital of the Jipang Duchy, which is currently seen as important by the Cepu community. This research shows that there are three important things related to the existence of Jipang Village. First, Arya Penangsang and the Duchy of Jipang for the Cepu Community. Second, the construction of the collective memory of the Cepu people. Third, the material culture of Arya Penangsang and the Duchy of Jipang.
\end{abstract}

Keywords: Jipang Village; hegemony; resistance; collective memory

\section{Introduction}

The problem of locality and local wisdom in Indonesia became a problem that received a lot of attention after the 1998 Reform. Based on Law Number 12 of 2008 on Regional Government, in carrying out regional autonomy, the region has one of the obligations to preserve socio-cultural values [2]. For district and city governments, this is an opportunity to improvise by involving various groups, such as academics, cultural figures, artists, community leaders, and others.

The characterization of Arya Penangsang in kethoprak Solo (Aryon Penangsang) [3] who took the source of the story from the Babad Tanah Djawi [4] represents the

\footnotetext{
* Corresponding author: sukarjowaluyo@gmail.com
} 
representation form of the Javanese ruler of Mataraman in remote Java, the Pajang Sultanate which was continued by the Mataram Sultanate and its heirs (Surakarta Palace, Keraton Yogyakarta, Mangkunegaran, and Pakualaman) for the benefit of hegemony. Barker revealed that hegemony could be understood within the framework of strategies in which the "rising-up" view of reality and power of social groups was maintained. Hegemony needs to be won again and negotiated constantly so that culture is an area of conflict and struggle for meaning [5].

On the other hand, the characterization of Arya Penangsang in Pati kethoprak (Ary Penangsang) plays the source of the story from a story on the north coast of Java (part of the Babad Tanah Djawi) and efforts to revitalize the triumph of the Jipang Duchy in Cepu representing a form of peripheral representation as a form of community resistance. Coastal, especially Cepu community. In general, the term resistance is used to refer to a challenging attitude or defiance in the context of the relationship of power and domination.

In the context of Cepu society, the heroism of the figure of Arya Penangsang is basically a cultural idea (with symbols, myths, and ceremonies) to imagine an event that actually did not occur at the present time. The story of Arya Penangsang involves as well as symbols, myths, and the story of the heroism of Arya Penangsang which until now can still be found. The Cepu community takes the opposite view in interpreting the figure of Arya Penangsang which is different from the perception of most Javanese people who believe more in the Babad Tanah Djawi. Babad Tanah Djawi depicts Arya Penangsang as the Duke of Jipang who is temperament, rude, evil, and hungry for power. In Cepu society, Arya Penangsang with all of her heroic stories becomes a respected and respected figure. The story still feels close to the community to this day. Behind its central figure for the Cepu community, there are many other things that accompany it that are able to build their collective memory which in Halbswach's perspective is a reconstruction of the past in a contemporary setting [6]. Collective memory is the cumulative of personal narratives, then personal narratives that have similarities are transmitted into collective memory.

The collective memory of the Cepu people who are proud of the figure of Arya Penangsang and the triumph of the Duchy of Jipang in the past appears in how they interpret the Gagak Rimang, the favorite horse of Arya Penangsang which is made an icon of the City of Cepu. The Cepu community also guarded the old tomb of the duchy of Astana Gedong Ageng (tomb of the duchy family), the former pavilion building next to Astana Gedong Ageng, and the former duchy area although it turned into a rice field area. Meanwhile, Bengawan Sore is still a sacred river. Some of these things are attached to the existence of Jipang Village which in the past became the center of Jipang Duchy government.

This research will reveal how Jipang Village which is closely related to the presence of Arya Penangsang is represented by the Cepu community who represent the Coastal Javanese community who are opposite the Javanese community at large. This is very reasonable because the defeat of Arya Penangsang for the Hadiwijaya attack made the Javanese royal power The largest coast in Java (the Demak Sultanate) in the mid-16th century had ended and was replaced by the power of the inland kingdom (the Pajang Sultanate continued by Mataram and its heirs).

Based on the background background above, the main problem developed in this article is how Jipang Village became a collective memory builder of the local history of the Cepu community. This research will reveal how the revitalization of infrastructure development, material culture, and cultural titles in Jipang shows that the Cepu people - especially after the passing of regional autonomy - are longing for the recognition of the triumph of their past buried history.

This research was conducted between April-August 2020. The data in this study are the material culture and the existence of Jipang Village which are related to the figures of Arya 
Penangsang and the Duchy of Jipang in Cepu. The data also came from interviews with several community leaders, local cultural figures, and the Jipang Keraton Foundation (interviews, documents, and work programs). This study uses ethnographic methods related to efforts to see the social cultural context of Cepu City related to Jipang Village. Spradley revealed that the essence of ethnography is an effort to pay attention to the meaning of the actions of events that happen to people we want to understand. Some of these meanings are expressed directly in language and among the accepted meanings, many are conveyed only indirectly through words and deeds. This meaning system is their culture and ethnography always implies cultural theory [7].

\section{Material Culture in Jipang Village as a Collective Memory Builder}

The Babad Tanah Djawi representing Javanese Mataraman / inland culture built a hegemony-style representation that departed from the figure of Arya Penangsang which was described as a bad figure. The strong influence of Mataraman culture centered in Solo and Jogja (as heirs / successors to the Sultanate of Pajang and the Sultanate of Mataram) made the story in the Babad Tanah Djawi considered by most Javanese people as a truth. This influence is seen in various cultural productions over a long period of time as seen in some arts and literature.

On the other hand, for the Cepu community in particular and the people of Coastal Java in general, Arya Penangsang with all of her heroic stories became a respected and respected figure. The story still feels close to the community to this day. The Cepu community took the opposite viewpoint in interpreting the figure of Arya Penangsang which was different from the perception of most Javanese people who believed more in the Babad Tanah Djawi writings. Behind the controversial figure of Arya Penangsang, there are many other things that accompany it that can build their collective memory.

Some of the perceptions of the Javanese people utilized in this study show that the history of power and politics in Java marked by the shifting of power in the Coastal Region (Demak) to the interior (Pajang and Mataram) is colored by a battle of regional interests and economic interests. The defeat of the figures of Arya Penangsang and the Duchy of Jipang at the same time marked the beginning of the triumph of the inland Java region and the collapse of the triumph of Coastal Javanese power. This past conflict also left a battle of two representations that continued to take place between the Coastal Java and the interior Java which were manifested in the perception of the supporting community and the cultural forms that emerged in the years that followed.

Cepu Subdistrict is located at the east end of Blora Regency and is bordered by Padangan District, Bojonegoro Regency, East Java Province. As one of the old cities in Java, Cepu became a magnet or center of several regions around Blora and Bojonegoro when talking about history, culture, and identity. With an area of $48.97 \mathrm{~km}^{2}$, a population of 77,880 people, and a density of 1,590 people $/ \mathrm{km}^{2}$, Cepu is the second largest city in Blora Regency [8].

In the view of some Cepu figures, the origin of the name Cepu itself is still being debated. Cepu as an area has been known since the days of Panembahan Senapati (Raja Mataram I) in power, precisely related to the struggle for the princess of Madiun named Retno Dumilah. There are also those who argue that the naming of Cepu is related to the story of the battle between Jipang and Pajang. Once upon a time, there was a Jipang soldier (there was an opinion not an ordinary soldier, but Arya Penangsang himself) who had a 
spear stuck in his thigh. In Javanese, step is nancep, thigh is pupu. The two words are combined into Cepu.

Cepu is also a city that is considered important during the Dutch colonial era because it is rich in oil and teak wood of the highest quality. The old wells that were formerly mined can still be seen today. In the era of the National Movement, Cepu became a place of exIndonesian Communist Party (PKI) Madiun escape which was then successfully crushed by the Ronggolawe Division under the leadership of GPH Djatikoesoemo. The name Ronggolawe is enshrined as Ronggolawe Field, Ronggolawe College of Technology (STTR), and Ronggolawe Monument. By the community, Ronggolawe Monument in the form of a horse statue was later perceived as a horse statue of Crow Rimang.

The Duchy of Jipang and Duke of Arya Penangsang (in Cepu better known as Arya Jipang) are two things that are very well known close and familiar to the people of Cepu and the surrounding area. As a sub-district, the history, culture and identity of Cepu has actually become a spirit and inspiration for various regions, especially in Blora in the eastern and western parts of Bojonegoro Regency. Therefore, when studying the history of the Sultanate of Demak and the Duchy of Jipang at school for example, the history teacher at Cepu will convey and explore the locality of Cepu to their students according to what students understand. There is no way he would speak of a general version of history in Java because Cepu's oral history was already known to his students as knowledge. History is not to make people go back to the past, capital builds Cepu forward in a political and economic perspective. This, for example, is realized by choosing Cepu as a historical and cultural tourism destination. Cepu itself is an area that has a complete history since prehistoric times, Hindu-Buddhist kingdoms, Islam, colonialism, and independent Indonesia, which needs to get the attention of local government policies.

Some Cepu figures also saw efforts to discredit Cepu since the defeat of Arya Penangsang whose bodies were buried in Kadilangu (Demak) as a sign that the authorities did not want to see Cepu as an area that had political, cultural and economic strength. In the case of the Madiun PKI and G30 S / PKI 1965, Cepu was perceived as a rebel area, even though Cepu's condition at that time was the same as other surrounding areas. As if there was an effort "Cepu is a rich area that must always be defeated." Meanwhile, in Cepu society a kind of belief emerged that Cepu people would find it difficult to develop if they did not migrate. "Get out of Cepu if you want to be a big person!", Adage which is often strung together by mentioning big names from Cepu, such as Mas Marco Kartodikromo, Tirto Adhi Soerjo, Kartosuwiryo, Mukti Ali, LB Murdani, and Pramudya Ananta Toer.

In 2014 the Jipang Keraton Foundation was established thanks to the hard work of the family who claimed to have a Jipang Duchy lineage. The Jipang Keraton Foundation document states that during Majapahit, Jipang was a small kingdom (covering five districts: Blora, Rembang, Pati, Kudus, and Bojonegoro) which had the right to regulate and be exempt from the obligation to pay tribute (In Javanese: perdikan). The destruction of Majapahit and the establishment of the Sultanate of Demak made Jipang self-deciphering (voluntarily joining) and turned into a duchy because of similar political views, especially related to the influence of Islamization on Coastal Java. When Demak was in conflict with the former Majapahit, Jipang was the main supporter of Demak, both in terms of geography (directly adjacent to enemy territory) and military donations (Laskar Soreng). Some say if Jipang loses the influence of Islam and Demak politics will lose, on the contrary if it wins Demak will become a major force as the heir to Majapahit's greatness.

In the view of local Cepu figures and cultural figures, the murder of Arya Penangsang for Sunan Prawata was purely for revenge and asking for "the right to return" to the throne of the Demak Sultanate in the past which should have fallen to Prince Sekar. Furthermore, Arya Penangsang enthroned himself as Sultan of Demak V in Jipang which later gave rise to the term Demak-Jipang. Regarding the Hadiwijaya attack, they said that in the view of 
the rebellious Cepu community was Hadiwijaya (Adipati Pajang). The reason is simple, rebels are parties and attack the center of the kingdom.

The Cepu community has a collective memory of the Arya Penangsang and the Duchy of Jipang which is inherent in history and culture that they understand. This is evident in the many sites and material culture that is still maintained in Jipang Village.

\section{Former Jipang Duchy Area}

The Cepu community understands that the former center of the Jipang Duchy is located in Jipang Village, about $7 \mathrm{~km}$ northwest of Cepu City. Jipang Village is now, the southern part is bordered by the Bengawan Solo River, the western part is bordered by Ngloram Village and Kapuan Village (separated by Bengawan Sore River turned into paddy fields), the northern part is bordered by Kapuan Village and Getas Village (separated by Kali Kecing River), and the part is east bordering dengas Getas Village (separated Kali Kecing River) and the Bengawan Solo River which protrudes inland and meets downstream Kali Kecing River.
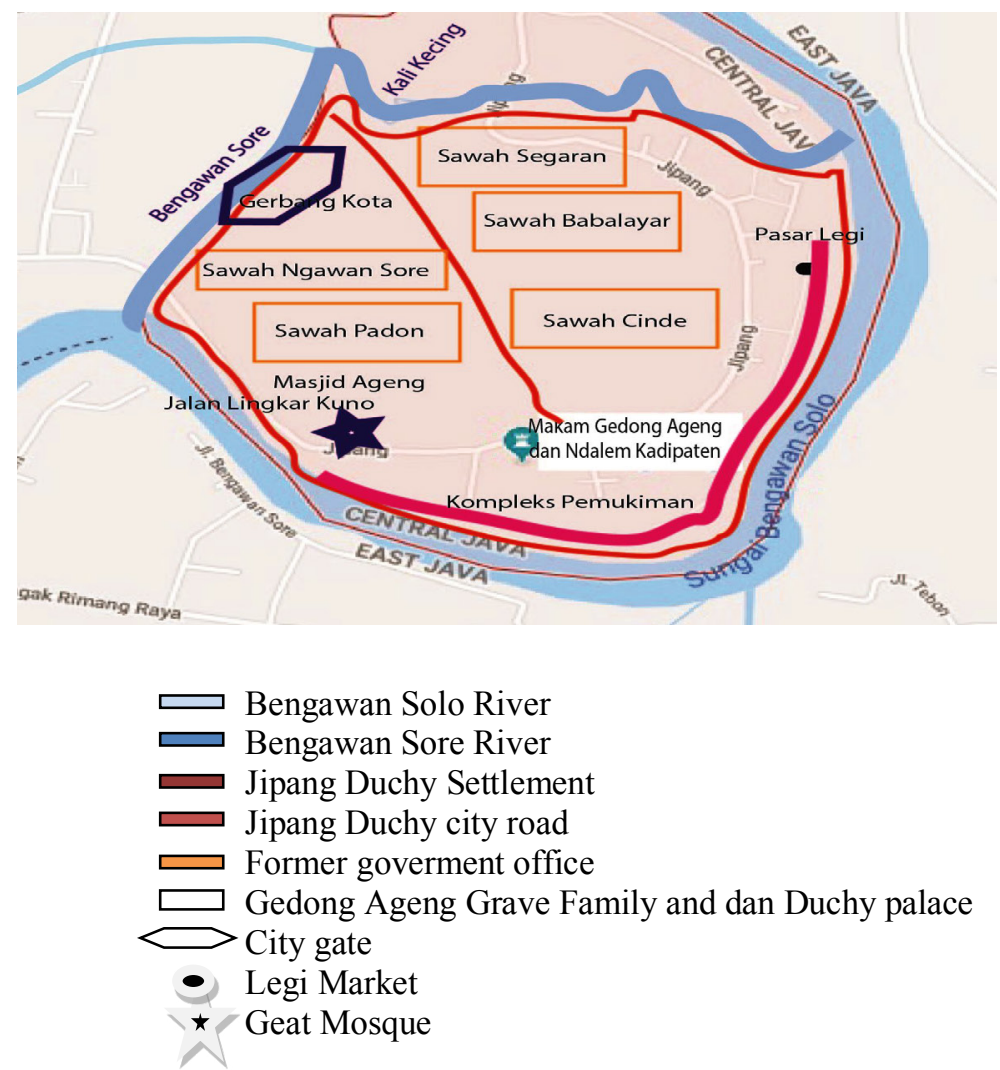

Fig. 1. Map of Jipang Village as the Former Seat of Jipang Duchy Government (Basic map: www.google.com/maps/place/Jipang)

This is reminiscent of how the center of the kingdom and the temple as a place of worship of the Javanese during the Hindu-Buddhist period which is usually located between a meeting of two rivers that reinforces the argument that Jipang is a former old kingdom. Some residents in Jipang Village are still very eloquent about what parts of the government buildings were established in the Duchy of Jipang. Even the fertile rice fields in Jipang Village still reflect the names of parts of the duchy building. Cinde rice field 
(Sawah Cinde) field shows the duchy garden. Padon rice field (Sawah Padon) shows court. Segaran rice field (Sawah Segaran) shows duchy ponds, the community also calls it Ngawan Anyar rice field (Sawah Ngawan Anyar). Babalayar rice field (Sawah Babalayar) shows the square which is commonly used for ceremonial events or performances. Ngawan Sore rice field (Sawah Ngawan Sore) which shows paddy fields in the former Bengawan Sore River.

\section{Gedong Ageng Family Grave and Duchy Pendopo}

This area is visited by many pilgrims who want to know more closely the story of Arya Penangsang and the Duchy of Jipang. Located next to the village road that divides Jipang Village, the two sites were built by the Blora Regency Government as a cultural heritage. The Gedong Ageng family grave is a place where Arya Penangsang was used to visit and often remember ancestors. Meanwhile, the new pavilion is now estimated to be the place where the duchy pavilion in the past stood.

\section{Bengawan Sore River and Floating Regions}

Jipang Village is between the confluence of two rivers (Bengawan Solo River and Kali Kecing River). In the past there was an initiative of the Duchy of Jipang to target Bengawan Solo River which was channeled to Kali Kecing River. As a result, Jipang appears as a floating area that is not easily entered by foreigners. Sodetan in the past functioned as a bastion / river fortress and the west gate which opened in the afternoon and closed in the morning guarded by Soreng soldiers so that it was named as Ngawan Sore (Bengawan Sore River). Bengawan Sore River also functions as an irrigation system that irrigates large rice fields around Jipang.

\section{Ancient Road Around Jipang Village}

The village of Jipang in the past was surrounded by the Bengawan Solo River, Kali Kecing River, and Bengawan Sore River and inside it was built a ring road. Currently the Jipang Village Government has begun to rebuild in several parts by paving roads which are part of the vision of the Jipang Village government to build a historical tourism village. There is a kind of community belief that if you build a house, you should face the road. Rows of houses appear facing Bengawan Solo River which is only limited by a small road. It can be said that Jipang is an area that is quite safe from the danger of overflow of the Bengawan Solo River. Residents are very sure that their ancestors had fortified their village's security from various dangers.

\section{Jipang, Jipang Panolan, or Jipang Panolang}

Javanese people outside Cepu often refer to the Jipang Duchy as Jipang, Jipang Panolan, or Jipang Panolang. Related to Arya Penangsang and the previous ruler the correct name is the Duchy of Jipang. Some time after the defeat of Jipang, Sultan Hadiwijaya appointed Prince Benawa (his son) as Duke of Jipang. However, because the central area of the duchy was destroyed by the war, Pangeran Benawa moved the duchy center about $1 \mathrm{~km}$ west of Jipang, called Panolan. The name Jipang Panolan appears, while the name Jipang Panolang is a misnomer by people outside Cepu (in the art of kethoprak or Soreng dance). At present, Jipang and Panolan are two different villages. Jipang Village is part of Cepu Subdistrict, while Panolan Village is part of Kedungtuban Subdistrict, both of which are part of Blora Regency.

\section{Jipang Village as the Center for History and Culture of Cepu}

The issue of locality and local wisdom with a historical and cultural background now began to appear in the City of Cepu. Some activities and events with historical and cultural 
backgrounds began to tend to be capitalized by young activists, cultural activists, communities, and the Blora District Government. Some of them are the appointment ceremony for the caretaker, cultural community, kothok coffee shop, Jipang culture and arts degree, recognition and existence of Jipang customs and culture as well as distinctive art from the heyday of the Jipang Duchy of the past, centered in Jipang Village..

\section{Conclucion}

The figure of Arya Penangsang and the Duchy of Jipang are inherent in the history and culture of the Cepu people. Arya Penangsang is their local hero. The glory of the Jipang Duchy of the past is their pride. This is evident in some sites and material culture that is still maintained can be witnessed in the village of Jipang. Jipang Village has an existence as a builder of their collective memory.

\section{References}

1. Jipang, Cepu, Blora - Wikipedia bahasa Indonesia, ensiklopedia bebas. https://id.wikipedia.org/wiki/Jipang,_Cepu,_Blora. Downloaded: 15-03-2017 09.50 UTC.

2. Undang-undang No. 12 Tahun 2008 tentang Pemerintahan Daerah. http://www.sanitasi.net/undang-undang-no-12-tahun-2008-tentang-pemerintahandaerah.html. Downloaded: 30-08-2017 13.05 UTC.

3. Waluyo, Sukarjo. 2019. Kontestasi Representasi Tokoh Arya Penangsang. Disertasi Universitas Indonesia. Jakarta.

4. Olthoff, W.L. 1987. Babad Tanah Djawi (De prozaversie van Ngabèhi Kertapradja voor het eerst uitgegeven door J.J. Meinsma en getranscribeerd door W.L. Olthof. Dordrecht-Holland: Foris Publications.

5. Barker, C. The Sage Dictionary of Cultural Studies (Terjemahan oleh B. Hendar Putranto) 2014. Yogyakarta: Penerbit Kanisius. p.120 (2003).

6. Halbwachs, Maurice. On Collective Memory. Chicago: University of Chicago Press. p.34 (1992).

7. Spradley, James P. Metode Etnografi. Yogyakarta: Tiara Wacana (2006).

8. Cepu, Blora - Wikipedia bahasa Indonesia, ensiklopedia bebas. https://id.wikipedia.org/wiki/Cepu, Blora. Downloaded: 15-03-2017 10.07 UTC. 